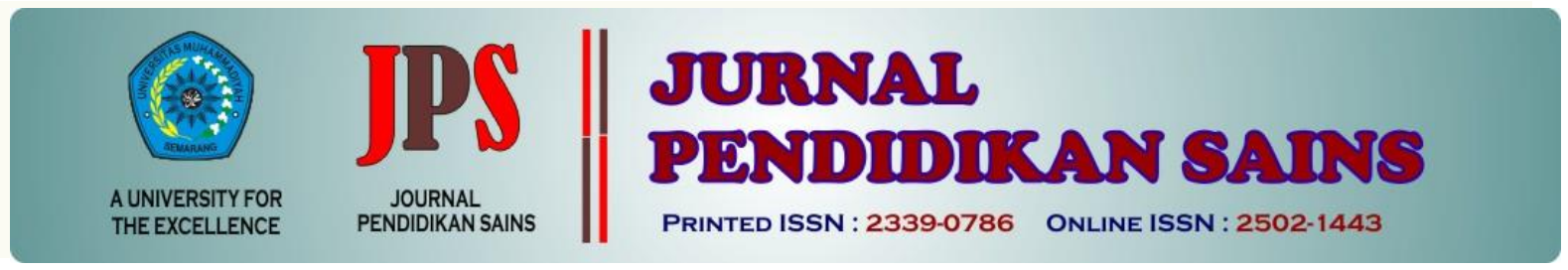

http://jurnal.unimus.ac.id/index.php/JPKIMIA

\title{
ANALISIS KEBUTUHAN PENGEMBANGAN PERANGKAT PEMBELAJARAN IPA SMP DI BALI DENGAN PENDEKATAN SAINTIFIK
}

\author{
Oleh: Gusti Ayu Oka Utami \\ Fakultas MIPA, Universitas Pendidikan Ganesha, Singaraja
}

\begin{tabular}{|c|c|c|}
\hline \multicolumn{2}{|c|}{ Article history } & \multirow{2}{*}{$\begin{array}{l}\text { Abstract } \\
\text { This study aims to analyze the ability of scientific work skills, junior high }\end{array}$} \\
\hline Submission & : 2020-07-21 & \\
\hline Revised & : 2020-09-07 & school science materials, and describe and explain the climate of junior \\
\hline Accepted & : 2020-09-16 & $\begin{array}{l}\text { high school science learning for development of learning instruments } \\
\text { with a scientific approach. This research is a descriptive study with }\end{array}$ \\
\hline \multicolumn{2}{|l|}{ Keyword: } & survey methods. The research population was all interested parties, \\
\hline \multicolumn{2}{|c|}{$\begin{array}{l}\text { Kata kunci: need } \\
\text { assessment, science } \\
\text { learning, scientific approach }\end{array}$} & $\begin{array}{l}\text { namely the organizers, class IX students, and the users of the graduates. } \\
\text { A total of } 495 \text { respondents were selected as samples determined by the } \\
\text { purposive sampling technique. Data of the scientific work skills and } \\
\text { science materials are analyzed descriptively. Learning climate data is } \\
\text { analyzed descriptively to determine the quality category of support for } \\
\text { the overall learning climate. The results showed that stakeholders } \\
\text { support the need for scientific work skills that need to be responded to } \\
\text { as much as } 92.7 \% \text {. The junior high school science programmed by the } \\
\text { curriculum can facilitate learning with a scientific approach of } 93.7 \% \text {. } \\
\text { Stakeholders assess the learning climate are considered adequate } \\
\text { (good) with a mean conversion score of } 4.33 \text {. }\end{array}$ \\
\hline
\end{tabular}

\section{Pendahuluan}

Capaian pendidikan sains di Indonesia masih berada dalam kategori rendah. Hal ini ditunjukan hasil Program for Internasional Student Assesment (PISA) dari waktu ke waktu. Pada tes pertama yang diikuti Indonesia yakni pada tahun 2003 kemampuan literasi sains siswa Indonesia berada pada urutan 38 dari 40 peserta, sedangkan tahun 2006 peringkat Indonesia berada pada urutan 50 dari 57 negara. Tahun 2009 peringkat Indonesia berada pada urutan 66 dari 67 negara peserta. Pada tahun 2012 kemampuan literasi sains siswa Indonesia berada pada peringkat 66 dari 67 negara peserta sedangkan pada tahun 2015 Indonesia menempati peringkat 69 dari 76 negara peserta (OECD, 2015). Data tersebut menunjukkan

*Corresponding Author:

$\begin{array}{ll}\text { Nama } & : \text { Gusti Ayu Oka Utami } \\ \text { Lembaga } & \text { : Universitas Pendidikan Ganesha } \\ \text { Email } & \text { : avuokautami@gmail.com }\end{array}$

bahwa literasi sains siswa Indonesia masih sangat rendah. Rendahnya literasi sains siswa salah satunya dapat disebabkan oleh kurang optimalnya proses pembelajaran sains di sekolah. Menurut Islami (2013) di Indonesia para pengajar sains nampaknya belum sepenuhnya memahami dengan baik tentang pembelajaran yang mengarah pada pembentukan literasi sains. Firman (2007) juga menjelaskan bahwa salah satu penyebab rendahnya kemampuan literasi sains siswa Indonesia disebabkan oleh pembelajaran yang bersifat tekstual dan kurang kontekstual. Contohnya adalah implementasi pendekatan pembelajaran konvensional yang cenderung memposisikan siswa sebagai pendengar dan bersifat pasif. Siswa hanya sebagai penerima pengetahuan dari guru. Siswa tidak 
memperoleh kesempatan secara optimal dalam mengkonstruksi pengetahuannya secara mandiri. Proses pembelajaran seperti ini cenderung tidak bersifat partisipatif sehingga siswa tidak merasa memiliki tanggung jawab belajar. Oleh karena itu, guru sains perlu melakukan perubahan pendekatan pembelajaran. Idealnya, guru sains mengimplementasikan pembelajaran inovatif yang mampu menumbuhkan tanggung jawab belajar pada diri siswa. Pendekatan pembelajaran saintifik adalah salah satu contoh pembelajaran yang inovatif. Implementasi pendekatan saintifik dapat memberikan kontribusi yang baik terhadap proses dan hasil belajar sains para siswa. Penelitian yang dilakukan oleh Sandoval \& Harven (2011) menunjukan bahwa pembelajaran inkuari sangat diminati oleh siswa dan pembelajaran ini menjadi satu kesatuan di dalam pendekatan saintifik. Pendekatan saintifik diyakini sebagai titian emas perkembangan dan pengembangan sikap, keterampilan, dan pengetahuan peserta didik.

Indonesia telah merekomendasikan pembinaan keterampilan proses sains sejak Kurikulum 1984 (cara belajar siswa aktif), Kurikulum 1994 (keterampilan proses sains), Kurikulum 2006 (asesmen otentik), dan Kuriukulum 2013 (pendekatan saintifik). Namun kualitas pendidikan sains di Indonesia untuk usia 15 tahun dalam dasa warsa terakhir tetap rendah. Hal ini dapat diketahui dari hasil rata-rata skor dunia untuk literasi adalah 487 , matematika 489, dan sains 498. Sedangkan di Indonesia rata-rata skor untuk literasi 371, matematika 379, dan sains 396 (OECD, 2016 Perangkat pembelajarn (RPP, LKPD, teks materi pelajaran, dan asesemen) yang konsisten dan selaras dengan penaralan induktid/deduktif sulit ditemukan di lapangan (Sudria, 2016).

Hal ini sejalan dengan penelitian yang dilakukan oleh Wiliyanti, Eko \& Abdurrahman (2015) bahwa perangkat pembelajaran IPA terpadu perlu adanya pengkajian kembali tentang identifikasi kebutuhan, kondisi sekolah (sarana dan prasarana sekolah), karakteristik siswa, dan waktu pembelajaran. Agar nilai kognitif, afektif dan psikomotor dalam perangkat pembelajaran dapat tersampaikan dengan baik, sebaiknya penilaian dapat dilakukan sekaligus melalui aktivitas pembelajaran, dengan dibantu oleh observer dalam mengamati aktivitas siswa atau dikenal dengan team teaching. Kekurang konsisten dan selarasnya pembelajaran saintifik juga didukung oleh penelitian yang dilakukan oleh Susbiyanto \& Insih (2016) agar pemanfaatan perangkat pembelajaran IPA berbasis Kurikulum 2013 dapat dilakukan diperlukannya kontribusi berbagai pihak salah satunya melalui Musyawarah Guru Mata Pelajaran (MGMP) IPA SMP/MTs sehingga perbaikan dan penyempurnaan perangkat dilakukan secara berkelanjutan. Selama ini pengembangan perangkat pembelajaran IPA SMP dengan pendekatan saintifik masih jauh dari harapan.

Pengembangan program pembelajaran perlu memepertimbangkan kebutuhan sesuai dengan jenis wilayah dengan karakteristik iklim belajarnya. Menurut Ramsey (2014) merekomendasikan bahwa dalam pengelolaan berbasis sekolah sangat penting memperhatikan iklim sekolah dan hubungannya dengan partisipasi berkelanjutan, diantaranya partisipasi dari orang tua siswa, para staff sekolah, guru, dan siswa. Sehingga keberadaan stakeholders sangat penting dalam keterlibatan menganalis iklim pembelajaran di sekolah. Pengembangan perangkat pembelajaran cendrung mulai dari sekolah wilayah kota.

Iklim belajar dapat dipengaruhi oleh faktor guru salah satunya pengetahuan profesional dan kemampuan profesional dari guru tersebut (Zhang, 2013). Keberadaan sarana pendukung pembelajaran khusunya ada tidaknya ruang laboratorium untuk faktor pembelajaran mata pelajaran IPA bisa dijadikan acuan menganalisis situasi/iklim belajar disekolah. Guru di Indonesia umunya merasa dan mengatakan sudah melakukan pembelajaran dengan pendekatan saintifik apabila melibatkan siswa dalam mengumpulkan data, walaupun siswa hanya sekedar mencatat hasil pengamatan yang hampir keseluruhan diberikan oleh guru dan bahkan sering kesimpulan temuan sudah disebutkan sebagai teori sebelum percobaan dilaksanakan, tidak melibatkan siswa dalam perumusan masalah, hipotesis dan rancangan percobaan pembuktian hipotesis (Sudria, 2016). Kondisi demikian tidak efektif membawa siswa ke arah belajar melalui penemuan oleh dirinya sesuai dengan pandangan konstruktivis atau belajar dengan pendekatan saintifik, dan cendrung memanjakan siswa yang berdampak pada kemalasan.

Iklim pembelajaran merupakan salah satu faktor penentu suatu kegiatan belajar mengajar yang efektif. Jika kegiatan belajar mengajar efektif, maka prestasi belajar 
mengajar siswa akan meningkat. Iklim pembelajaran yang diartikan sebagai rasa belajar dimana siswa merasakan suasana pembelajaran di dalam kelas maupun di lingkungan sekolah (Sudjana, 2002).

Suasana lapangan tersebut tidak terlepas dari kurang tersedianya unit-unit perangkat pembelajaran yakni RPP, LKS, teks materi pelajaran, dan asesmen dengan pendekatan saintifik yang selaras dan konsisten (Sudria, 2016). Kenyamanan guru maupun siswa belajar melalui penerimaan (root learning) sudah berlangsung cukup lama. Di samping itu, pengembangan suatu program pembelajaran akan melibatkan banyak orang yang berkepentingan. Agar produk pengembangan tidak sia-sia dan mempunyai peluang untuk diterapkan, maka dukungan data analisis kebutuhan dan iklim belajar yang diungkap dari variasi kelompok stakeholders diperlukan dalam rangka perangkat pemebalajaran IPA SMP dengan pendekatan saintiifik yang konsisten dan selaras.

Iklim sekolah dapat berkaitan dengan jenis lokasi wilayah. Definisi jenis wilayah atau klasifikasi wilayah bervariasi di berbagai negara. Klasifikasi wilayah umumnya menggunakan kriteria kerapatan jumlah penduduk, besar pendapatan dan/atau kualitas layanan (Pateman, 2011; Stokes, Stafford, \& Holdsword, 1999). Dalam konteks interaksi antara masyarakat dikenal kategori wilayah pusat kota (city), sub-daerah perkotaan (suburban), jalur tepi sub-daerah (sub-urban fringe) sebagai peralihan kota dan desa, jalur tepi perkotaan paling luar (urban fringe), jalur batas desa dan kota (rural uraban fringe), dan daerah pedesaan atau rural (Utami \& Kurniawati, 2018).

Dalam konteks administrasi pemerintahan di Indonesia, kota adalah pembagian wilayah administratif di Indonesia setelah provinsi, yang dipimpin oleh seorang wali kota. Selain kota, pembagian wilayah administratif setelah provinsi adalah kabupaten.

Secara umum, baik kabupaten dan kota memiliki wewenang yang sama. Kabupaten bukanlah bawahan dari provinsi, karena itu bupati atau wali kota tidak bertanggung jawab kepada gubernur. Kabupaten maupun kota merupakan daerah otonom yang diberi wewenang mengatur dan mengurus urusan pemerintahannya sendiri (Creswell, 2008).

Untuk wilayah yang kecil dengan karakteristik tertentu dan untuk kepentingan tertentu, klasifikasi wilayah atas kota dan desa cukup memadai. Lavesson (2017) berfokus pada desa (rural) dan kota (urban) dalam studi Rural-Urban Interdependencies. Keberadaan sub-urban sering kurang jelas. Bali merupakan wilayah propinsi kecil sebagai tujuan wisata internasional. Orang desa yang berkativitas di ibu kota kabupaten dapat pulang dan pergi dari tempat tinggal di desa. Namun jika dilihat dari tempat tinggal siswa subjek belajar saat ini di Bali dengan ketersediaan sekolah yang cukup, mereka cendrung menetap di kota atau desa tempat mereka bersekolah. Dengan demikian dalam konteks analisis iklim belajar, cukup beralasan wilayah lokasi sekolah di Bali hanya dibedakan atas wilayah kota dan wilayah desa. Kota diindikasikan oleh sistem pemerintahan kewilayahan dalam bentuk kelurahan dengan kepala pemerintahan disebut Lurah, sedangkan desa diindikasikan sistem pomerintahan kewilayahan dalam bentuk desa dengan kepala pemerintahan disebut Kepala Desa.

Walaupun demikian adanya kemungkinan pengaruh perbedaan iklim sekolah di kota dan di desa terhadap proses dan hasil belajar tetap perlu dipertimbangkan dalam memberikan batasan penelitian yang tidak mengkaji kedua iklim bersamaan secara kopmrehensif. Karena keterbatasan waktu studi, tenaga , dan biaya, studi hanya dibatasi pada wilayah kota kabupaten. Menurut Li (2014) perlu dilakukan analisis kebutuhan pembelajaran sebagai pedoman untuk memenuhi kebutuhan berbagai pemangku kepentingan saat merancang kurikulum IPA. Program pembelajaran dapat dipandang sebagai kurikulum dalam dimensi mikrokurikulum atau classroom (Sudjana, 2004)

Analisis kebutuhan tidak diragukan lagi merupakan cara yang efektif untuk mendesain program pembelajaran IPA. Dari latar belakang di atas dalam rangka pengembangan perangkat pembelajaran dengan pendekatan saintifik, maka perlu menganalisis kebutuhan pembelajaran IPA SMP pada wilayah kota.

\section{Metode Penelitian}

Jenis Penelitian

Penelitian ini menggunakan metode survei yang dilakukan secara purposive sampling.

Target/Subjek Penelitian

Survei dilakukan secara purposive sampling. Penentuan Kota Bali sebagai tempat penelitian dikarenakan Kota Bali sering 
menjadi salah satu rujukan nasional. Adapun penentuan sampel penelitian menggunakan teknik sampling dilakukan berdasarkan 3 pertimbangan berikut.

Pertama, sampel SMP mewakili kota yang tersebar di Bali. Sampel hanya terdiri dari 5 buah kota kabupaten yaitu Singaraja (Bali bagian utara), Amlapura (Bali bagian timur), Gianyar (Bali bagian tengah), Mangupura dan Denpasar (Bali bagian selatan), dan Negara (Bali bagian barat).

Kedua, sampel meliputi kelompokkelompok stakeholders pembelajaran IPA SMP dengan jumlah yang berimbang dari setiap kelompok untuk mengkonfirmasi kesamaan respon dari semua kelompok. Kesamaan respon dari setiap kelompok stakeholder penting dalam merumuskan kebutuhan dan iklim belajar yang diharapkan.

Ketiga, distribusi keberadaan kelompok-kelompok stakeholders tidak sama, tetapi intensitas perhatian pihak-pihak stakeholders seperti pihak penyelenggara yang paling tahu dengan kebutuhan dan iklim sekolah sangat penting. Pentuan jumlah sampel dari setiap kelompok secara berimbang dibastasi oleh jumlah sampel dari pihak penyelenggara yang ada di SMP sampel. Jumlah sampel dari pihak penyelenggara untuk setiap SMP terbatas 10 orang, biasanya terdiri dari enam orang guru IPA, satu orang wakil kepala sekolah urusan kurikulum, dan satu orang pengawas mata pelajaran IPA. Pihak dari Kantor Departeman Pendidikan Kabupaten diwakili oleh dua belas orang Pengawas Mata Pelajaran IPA. MGMP IPA SMP untuk Kabupaten (masing-masing kabupaten yang digunakan sebagai sampel penelitian). Responden dari MGMP hanya diwakili oleh sampel guru-guru IPA yang semuanya sebagai ketua atau anggota MGMP.

Dengan adanya keterbatasan jumlah sampel dari pihak penyelenggara yang sesungguhnya paling tahu dengan kebutuhan dan iklim belajar di sekolah dan pertimbangan keterwakilan dari siswa dengan kemampuan baik (3 orang atau $25 \%$ ), sedang (6 orang atau $50 \%$ ), dan kurang (3 orang atau $25 \%$ ), maka jumlah sampel setiap pihak untuk satu SMP sampel diambil 12 orang. Demikian juga jumlah sampel pihak pengguna lulusan SMP sampel sebanyak 12 orang yang terdiri dari seksi komite sekolah SMP, guru IPA SMA (Fisika, Biologi, Kimia) dan wakil urusan kurikulum dari SMA terdekat dengan SMP sampel cendrung dapat dipenuhi.
Rancangan jumlah sampel terdiri dari 36 orang untuk setiap kelompok stakeholders di setiap kota yang dijadikan sampel. Jadi secara keseluruhan rancangan jumlah sampel keseluruhan survei untuk wilayah bali sebanyak 540 orang. Realisasi sampel dalam survei dari 540 adalah 495 orang $(91,6 \%)$ untuk stakeholders

\section{Prosedur}

Survei menggunakan angket kebutuhan dan iklim pembelajaran dalam rangka pengembangan perangkat pembelajaran dengan pendekatan saintifik yang dikembangkan bersama dengan anggota penelitian. Angket telah divalidasi oleh 3 orang ahli yang terdiri dari 1 orang dosen ahli pendidikan Biologi, 1 orang dosen ahli pendidikan Fisika, dan 1 orang dosen ahli pendidikan Kimia. 3 orang praktisi yang terdiri dari 3 orang guru SMP dengan hasil validasi tergolong rata-rata baik.

Tanggapan terhadap survei kebutuhan keterampilan kerja ilmiah dan isi/materi pokok dikumpulkan melalui angket dengan butir pilihan yang meminta responden untuk menyetujui $(\mathrm{P}=$ perlu $)$ atau menolak $(\mathrm{TP}=$ tidak perlu) untuk setiap butir rumusan kebutuhan yang ditawarkan. Sementara tanggapan/penilaian terhadap iklim belajar dengan pendekatan saintifik juga diungkap dengan angket tetutup (pilihan), tetapi tanggapan pilihan untuk setiap butir pernyataan disediakan dalam bentuk rubrik penilaian gradasi kualitas skala lima (skala Likert). Angket juga dilengkapi beberapa butir pertanyaan terbuka untuk menginventaris usulan dan tanggapan lain dari responden yang belum terwakili oleh butir-butir angket pilihan. Analisis kebutuhan keterampilan kerja ilmiah dan materi/isi IPA menggunakan data deskriptif dengan presentase penerimaan kebutuhan oleh stakeholders dan untuk penentuan signifikansi penerimaan butir oleh ketiga pihak responden menggunakan uji-z terhadap proporsi responden yang setuju. Uji penolakan dilakukan pada proporsi 0,5 karena peluang responden setuju dan tidak setuju adalah sama. Sementara analisis iklim belajar IPA dengan pendekatan saintifik dilakukan secara deskriptif untuk menentukan kategori kualitas dukungan situasi secara keseluruhan.

$$
\text { Kategori kualitas situasi }
$$

dikelompokkan menggunakan skala Likert dengan konversi rentangan ideal yakni $\mathrm{x}>4,5$ (sangat baik), 3,5 $<\mathrm{x} \leq 4,5$ (baik), $2,5 \leq \mathrm{x} \leq 3,5$ 
(cukup), $1,5 \leq \mathrm{x}<2,5$ (kurang), dan $\mathrm{x} \leq 1.5$ (sangat kurang) (Riduwan, 2012).

\section{Hasil Penelitian dan Pembahasan}

Survei kebutuhan dan iklim belajar IPA dengan pendekatan saintifik berjalan sesuai rencana dengan tingkat partisipasi stakeholders adalah cukup tinggi yakni 495 orang $(91,6 \%)$. Komposisi keterwakilan kelompok stakeholders yang mengembalikan isi angket adalah 143 orang $(28,8 \%)$ penyelenggara, 180 orang $(36,3)$ siswa, dan 172 orang $(34,7 \%)$ pengguna lulusan.

Data rerata persentase responden yang menerima keseluruhan butir kebutuhan keterampilan kerja ilmiah dan isi/materi pokok IPA SMP dari pihak penyelenggara $(\mathrm{P})$, siswa $(\mathrm{S})$, dan pengguna $(\mathrm{G})$, serta hasil uji-z dan signifikansinya disajikan dalam Tabel 1 .

Tabel 1. Rerata persentase responden mengakui kebutuhan kerja ilmiah dan isi/materi pokok IPA SMP pada wilayah kota di Bali

\begin{tabular}{|c|c|c|c|}
\hline \multirow[t]{2}{*}{ Kebutuhan } & \multicolumn{2}{|c|}{$\begin{array}{c}\text { Stakeholders } \\
(\%)\end{array}$} & \multirow[t]{2}{*}{$\begin{array}{c}\text { Rerata } \\
(\%)\end{array}$} \\
\hline & $\mathrm{P}$ & $\mathrm{G}$ & \\
\hline $\begin{array}{l}\text { Keterampilan } \\
\text { kerja ilmiah }\end{array}$ & $92,2 \quad 90,9$ & 95,4 & 92,7 \\
\hline Z; Sig & \multicolumn{2}{|c|}{71,$29 ; 0,000$} & \\
\hline $\begin{array}{l}\text { Isi/materi pokok } \\
\text { IPA SMP }\end{array}$ & $94,691,5$ & 96,9 & 93,7 \\
\hline Z; Sig & 113,$67 ; 0$, & 000 & \\
\hline
\end{tabular}

Keseluruhan butir aspek keterampilan kerja ilmiah, yang ditawarkan diterima secara signifikan oleh $92,7 \%$ stakeholders dan isi/materi pokok yang ditawarkan diterima secara signifikan oleh $92,7 \%$ stakeholder. Keduanya diterima tanpa terjadi perbedaan pendapat antar kelompok stakeholders.

Sementara deskripsi rerata skor penilaian keseluruhan butir iklim belajar saintifik oleh kelompok penyelenggara $(\mathrm{P})$, siswa $(\mathrm{S})$, dan pengguna $(\mathrm{G})$ disajikan dalam Tabel 2.

Tabel 2. Rerata skor iklim belajar SMP pada wilayah kota di Bali untuk keseluruhan butir

\begin{tabular}{cccc}
\hline \multicolumn{3}{c}{ Stakeholders } & Rerata \\
\cline { 1 - 3 } $\mathrm{P}$ & $\mathrm{S}$ & $\mathrm{G}$ & keseluruhan \\
\hline 4,40 & 4,32 & 4,28 & 4,33 \\
\hline
\end{tabular}

Iklim pembelajaran saintifik secara keseluruhan dinilai baik dengan rerata skor terendah $(4,28)$ diberikan oleh kelompok pengguna (orang tua, komite sekolah, dan guru Fisika, Biologi, dan Kimia SMA) dan tertinggi
$(4,40)$ diberikan oleh kelompok penyelenggara (guru IPA SMP dan Wakil Kepala sekolah urusan Kurikulum). Penilain iklim pembelajaran oleh kelompok siswa juga tergolong baik dengan rerata skor 4,28 (terletak diantara rerata skor penilaian oleh kelompok penyelenggara dan pengguna). Semua kelompok stakeholders menilai situasi dengan kategori baik.

Kebutuhan keterampilan kerja ilmiah dianggap perlu dan didukung oleh 92,7\% stakeholders. Aspek-aspek tersebut mewakili keterampilan kerja ilmiahShe mengamati, menanya, mengumpulkan data, mengasosiasi, dan mengkomunikasi. Hasil penelitian ini didukung oleh Sandoval \& Harven (2011), bahwa pembelajaran inkuiri sangat diminati oleh siswa dan pembelajaran ini menjadi satu kesatuan di dalam keterampilan proses sains (kerja ilmiah).

Kebutuhan keterampilan kerja ilmiah yang meliputi 14 aspek yang terdiri dari 2 aspek mengamati, 2 aspek menanya, 3 aspek merencanakan, 5 aspek mengasosiasi, dan 2 aspek mengomunikasikan. Keterampilan mengamati terdiri dari dua butir yaitu aspek (1) menemukan informasi relevan/penting dalam fenomena pengantar (deskripsi objek/konteks belajar pada awal LKPD dan teks materi pelajaran) dan gejala alam terkait yang ada di sekitar sebagai latar belakang belajar dengan pendekatan saintifik, dan (2) mengelompokkan informasi awal tersebut ke dalam konsep awal prasyarat dan informasi baru. Keterampilan mengamati informasi awal yang relevan dengan pengetahuan yang akan dibangun sangat penting untuk mengarahkan fase saintifik berikunya (menanya saintifik). Menurut Adam \& Gullota, (1983) keberhasilan pada fase awal dalam suatu kegiatan yang sistematis seperti kegiatan ilmiah akan membuka peluang keberhasilan atau feasibitas suatu program. Sebaliknya kegagalan dalam melaksanakan fase awal dari suatu sistem sangat kecil memberi peluang keberhasilan seluruh kegiatan dari suatu program yang sitematik tersebut. Pembelajaran sesuai kaidah inkuiri secara konsisten dapat diterapkan untuk pendidikan pada jenjang SMP (usia 11-15 tahun), karena ini merupakan fase operasi formal atau abstraksi sehingga dapat menghasilkan terjadinya perkembangan berpikir yang sangat tajam.

Pembelajaran sains secara berkualitas pada jenjang SMP memiliki makna strategis dari pandangan konstruktivis yang menekankan 
pentingnya kualitas pengetahuan/konsepsi awal dalam menentukan kelancaran belajar sains lebih lanjut (Sudria, 2006). Hasil penelitian ini juga didukung oleh Arianty et al., (2017), bahwa kebutuhan keterampilan kerja ilmiah pada aspek mengamati tergolong sedang yaitu $73,98 \%$. Walaupun aspek mengamati tergolong sedang setidaknya secara keseluruhan aspek mengamati dalam keterampilan proses sains memang sangat diperlukan.

Keterampilan menanya terdiri dari dua aspek: (1) bertanya terkait dengan kejelasan informasi dalam fenomena pengantar atau gejala alam di sekitar yang diamati, dan (2) merumuskan masalah investigatif atau pertanyaan yang akan dicari jawaban/ pemecahannya sesuai dengan pengetahuan konseptual yang dikonstruksi. Kedua aspek ini penting, terutama aspek kedua yang semestinya harus berhasil. Menurut penelitian Shen, (2007) pembelajaran inkuiri merupakan pembelajaran melalui penemuan/investigasi. Aspek pertama, pertanyaan klarifikatif terhadap informsi awal yang relevan diperlukan untuk mengarahkan ketepatan merumuskan masalah investigasi yang akan menentukan kebenaran dan ketepatan fase mengumpulkan data berikutnya. Kebenaran dan ketepatan rumusan masalah kearah pengetahuan yang akan menjadi target pembelajaran akan menentukan ketepatan rumusan hipotesis sebagai acuan pengumpulan data dan semua kegiatan ilmiah secara keseluruhan. Sejalan dengan penelitian Sandoval \& Harven (2011) pertanyanpertanyaan investigatif mampu meningkatkan nilai siswa. Siswa menemukan tugas penyelidikan yang menarik dan berguna pula untuk meningkatkan nilai belajar mereka.

Keterampilan mengumpulkan data (mencoba/merencanakan) dari tiga aspek utama: (1) merumuskan hipotesis sesuai dengan rumusan masalah investigasi (rumusan masalah hipotetik), (2) merancang pembuktian hipotesis (rancangan pengumpulan data) yang meliputi: menentukan variabel-variabel dari hipotesis (variabel bebas, terikat, dan kontrol), membuat disain data pembuktian hipotesis (variasi nilai/aspek variabel bebas dan variabel terikat), menentukan alat dan bahan, menyusun cara kerja, dan membuat format pencatatan data, dan (3) melakukan pengambilan data (pengamatan dan pencatatan data) sesuai dengan format pencatatan data yang dirancang. Seperti telah disebutkan, rumusan hipotesis merupakan acuan mengumpulkan data secara efektif dan acuan kegiatan fase-fase berikutnya (mengasosiasi dan mengkomunikasi proses dan hasil kegiatan ilmiah).

Hasil National Academy of Science. (1996) dan OECD (2016) menyebutkan bahwa kegiatan inkuiri/saintifik dalam sains melibatkan identifikasi masalah investigatif yang secara optimistik akan dapat dijawab melalui investigasi ilmiah; mendesain dan melaksanakan investigasi; menggunakan alat dan teknik yang cocok dalam mengumpulkan, menganalisis, dan mengintepretasikan data; mengembangkan deskripsi, penjelasan, dan model menggunakan fakta; dan berpikir secara kritis dan kreatif untuk membuat hubungan antara fakta dan penjelasan

Tanpa rumusan hipotesis yang benar dan tepat cendrung mengakibatkan keseluhan kegiatan 5M saintifik mubasir, karena semua fase-fase kegiatan $5 \mathrm{M}$ saintifik akan mengacu pada pengetahuan yang menjadi target. Rumusan hipotesis berasal dari terkaan yang dibuat berdasarkan pada sebuah pedoman atau acuan yaitu teori dan fakta ilmiah. Respon penerimaan terhadap aspek merancang pembuktian hipotesis tersebut secara insplisit merupakan pengakuan keseluruhan stakeholders terhadap keterampilan menentukan variabel-variabel dari hipotesis (variabel bebas, terikat, dan kontrol), membuat desain data pembuktian hipotesis (variasi nilai/aspek variabel bebas dan variabel terikat), menentukan alat dan bahan, menyusun cara kerja, dan membuat format pencatatan data. Sementara aspek-aspek ini kurang jelas dan kurang tegas panduannya baik dalam Permendikbud terkait dengan standar isi, standar proses, maupun standar penialaian dalam Kurikulum 2013 atau kurikulumkurikulum sebelumnya. Sesungguhnya ketepatan identifikasi variabel-variabel setiap hipotesis akan mengarahkan secara berkelanjutan pada efektifitas dan kejelasan rancangan pembuktian pembuktian hipotesis, ketepatan pemilihan alat dan bahan, penyusunan prosedur kerja, dan lembar/tabel pengumpulan data. Kegiatan pengumpulan data akan efektifitas dan lancar jika rancangan pembuktian pengumpulan data secara konsisten melibatkan tahapan-tahapan kegiatan pembuatan rancangan pengumpulan data yang semestinya mendahuluinya.

Keterampilan mengasosiasi meliputi lima aspek: (1) mengolah data yang diperoleh sehingga menunjukkan hubungan sebab dan akibat antara data variasi nilai/aspek variabel bebas dan variasi nilai variabel terikat sesuai 
dengan hipotesis yang terkait (setiap hipotesis), (2) mengerjakan tahapan-tahapan analisis data (menjawab pertanyaan-pertanyaan) terkait kearah penarikan kesimpulan untuk setiap hipotesis, (3) mencocokan kesesuaian hasil analisis data dengan konsep/teori dalam pustaka sumber, (4) mendiskusikan hasil analisis data, dan (5) membuat kesimpulan hasil kegiatan ilmiah (saintifik) serta menyatakan penerimaan atau penolakan rumusan hipotesis yang bersangkutan. Permendikbud Nomor 81a Tahun 2013, mengatakan bahwa kegiatan mengasosiasi adalah memproses informasi yang sudah dikumpulkan baik terbatas dari hasil kegiatan mengumpulkan/eksperimen maupun hasil dari kegiatan mengamati mengumpulkan informasi. Pengolahan informasi yang dikumpulkan dari yang bersifat menambah keluasan dan kedalaman sampai kepada pengolahan informasi yang bersifat mencari solusi dari berbagai sumber yang memiliki pendapat yang berbeda sampai kepada yang bertentangan. Kegiatan ini dilakukan untuk menemukan keterkaitan satu informasi dengan informasi lainnya, menemukan pola dari keterkaitan informasi tersebut.

Adapun kompetensi yang diharapkan adalah mengembangkan sikap jujur, teliti, disiplin, taat aturan, kerja keras, kemampuan menerapkan prosedur dan kemampuan berpikir induktif serta deduktif dalam menyimpulkan. Aktivitas ini juga diistilahkan sebagai kegiatan menalar, yaitu proses berfikir yang logis dan sistematis atas fakta-fakta empiris yang dapat diobservasi untuk memperoleh simpulan berupa pengetahuan. Aktivitas menalar dalam konteks pembelajaran pada kurikulum 2013 dengan pendekatan ilmiah banyak merujuk pada teori belajar asosiasi atau pembelajaran asosiatif. Istilah asosiasi dalam pembelajaran merujuk pada kemampuan mengelompokkan beragam ide dan mengasosiasikan beragam peristiwa untuk kemudian memasukkannya menjadi penggalan memori. Selama mentransfer peristiwa-peristiwa khusus ke otak, pengalaman tersimpan di memori otak berelasi dan berinteraksi dengan pengalaman sebelumnya yang sudah tersedia.

Keterampilan

mengkomunikasi meliputi dua aspek: (1) membuat naskah bentuk komunikasi kerja ilmiah yang dilakukan (laporan, poster, atau naskah presentasi), dan (2) mempresentasikan proses dan hasil kegiatan ilmiah (saintifik). Komunikasi kegiatan ilmiah (proses dan hasil) dapat dilakukan melalui penulisan laporan, poster, dan/atau presentasi.
Penyiapan naskah bentuk laporan kegiatan ilmiah (proses dan hasil) perlu dilakukan untuk mendukung keberhasilan komunikasi kegiatan kerja ilmiah yang telah dilakukan. Di samping itu, naskah bentuk komunikasi ilmiah diperlukan untuk memenuhi tuntutan keandalan (reliabilitas) suatu laporan kegiatan ilmiah. Menurut Chatab, (2007), keterampilan komunikasi merupakan kemampuan mengadakan hubungan lewat saluran komunikasi manusia atau media, sehingga pesan atau informasinya dapat dipahami deangan baik.

Berdasarkan hasil kajian beberapa sumber pustaka global dan alokasi waktu belajar IPA SMP sesuai dengan kurikulum yang berlaku, keluasan cakupan dan kedalam isi/materi IPA SMP sudah dianggap memadai. Keseluruhan materi pokok tersebut dalam angket terdiri dari 33 butir rumusan. Semua butir rumusan materi pokok tersebut juga diterima oleh $93,7 \%$ stakeholders dengan tanpa terjadi ketidaksamaan respon. Hal demikian menunjukkan kajian pengembang terhadap kecukupan materi pokok pelajaran IPA SMP dalam kurikulum 2013 diperkuat oleh tanggapan stakeholders. Materi-materi pokok tersebut cukup mendasar dan berguna untuk studi lanjut maupun sebagai bekal untuk terjun kemasyarakat, serta cukup kaya mengandung pengetahuan konseptual, prosedural, dan faktual yang terkait, sehingga kondusif dikonstruksi secara saintifik pada jenjang SMP. Hasil penelitian ini didukung oleh Hewitt, (2007) yang menyatakan bahwa sains terpadu menyajikan aspek fisika, kimia, biologi, ilmu bumi, astronomi dan aspek lainnya dari Ilmu Pengetahuan Alam. Dalam bukunya Conceptual Integrated Science, IPA terintegrasi disajikan berbasis pendekatan kontekstual yaitu menghubungkan sains dengan kehidupan sehari-hari, bersifat personal dan langsung, menempatkan salah satu ide pokok, mengandung pemecahan masalah. Dalam penyajiannya, IPA disajikan dengan kesatuan konsep. Hasil penelitian ini sejalan dengan penelitian yang dilakukan oleh Trefil \& Hazen (2007) mengungkapkan bahwa pendekatan terintegrasi (An integrated approach) melibatkan proses ilmiah, mengorganisasikan prinsip, mengorganisasikan integrasi alam dari pengetahuan ilmiah dan aplikasinya dalam kehidupan sehari-hari. Disamping itu, dalam an integrated approach ini juga siswa diharapkan mampu mengkaitkan dalam bidang lain meliputi fisika, astronomi, kimia, geologi, 
biologi, teknologi, lingkungan, dan kesehatan keselamatan.

Survei ini juga berhasil mengungkap dukungan iklim pembelajaran IPA dengan pendekatan saintifik oleh stakeholders Sebanyak 27 butir aspek iklim pembelajaran yang diorganisasikan ke dalam lima aspek umum situasi dinyatakan oleh stakeholders tergolong baik dengan rerata skor 4,33.

Beberapa butir iklim khusus ketersediaan perangkat pembelajaran dengan pendekatan saintifik yang tergolong baik meliputi pengembangan PBS keseluruhan, ketersediaan LKPD, kegiatan belajar, dan bimbingan belajar. Sementara ketersediaan buku sumber dan langkah-langkah pembelajaran dengan pendekatan saintifik tergolong sangat baik. Butir iklim yang mendukung pelaksanaan PBS yang tergolong baik oleh stakeholders antara lain media pembelajaran, ruang belajar dikelas, dan fasilitas di kelas. Butir iklim yang mendukung pelaksanaan PBS yang tergolong sangat baik dengan rerata skor > 4,5 yaitu keberadaan laboratorium IPA dan perpustakaan sekolah. Lima dari enam butir iklim yakni sarana yakni buku/sumber belajar lain tergolong sangat baik dengan rerata skor $>4,5$. Media pembelajaran, LKPD, laboratorium, dan fasilitas belajar di rumah tergolong baik dengan rerata skor 3,54,5. Kecuali buku/sumber belajar dan LKPD, tiga dari lima aspek sarana belajar yang tergolong baik cukup realistis. Hasil penelitian ini sejalan dengan penelitan yang dilakukan oleh Wahyono, et al., (2017) bahwa bahwa ketersedian buku/sumber belajar dan LKPD dengan pendekatan saintifik sangat kurang, diakibatkan kurangnya kemampuan guru dalam mengembangkan perangkat pembelajaran dengan pendekatan saintifik. Pelatihan keterampilan saintifik guru perlu dilakukan secara berkala.

Media pembelajaran tergolong sangat baik dengan rerata skor $>4,5$ serta cukup bervariasi dan mudah diakses secara online oleh guru dan peserta didik. Laboratorium untuk jenjang SMP umumnya dalam konteks pengambilan data IPA yang cendrung kualitatif (ketelitian tidak sebagai sasaran utama) cukup memadai di Bali dan bahkan banyak dapat menggunakan alam sekitar. Namun, tidak dapat dipungkiri bahwa keberadaan laboratorium IPA sangat mendukung keberhasilan pembelajaran IPA dengan pendekatan saintifik. Proses pembelajaran IPA tidak cukup pada teori saja namun juga perlu adanya pembuktian- pembuktian ilmiah dimana dapat dibuktikan melalui kegiatan praktikum. Sehingga peran laboratorium sangatlah dibutuhkan dalam kegiatan pembelajaran di sekolah.

Fasilitas belajar di rumah di Bali tergolong baik dengan rerata skor 3,5 - 4,5. Hampir semua siswa di Bali tinggal di rumah orang tua (meskipun ada yang sederhana), kamar kotrakan, atau asrama dengan penerangan listrik yang memadai. Hampir tidak ada siswa yang tinggal di kolong jembatan atau tempat lain serupa. Penilaian terhadap ketersediaan buku/sumber belajar dan LKPD yang tergolong baik cendrung karena tidak adanya acuan (benchmark) yang jelas dan konsisten tentang kriteria masing-masing aktivitas mengamati, menanya, mengumpulkan data, mengasosiasi, dan mengkomunikasi yang tergolong ilmiah. Seperti telah diungkap dalam latar belakang, kebanyakan guru tidak bisa sebagai fasilitator, mereka cenderung menyuapi pesera didik dengan jawaban yang dimana seharusnya peserta didik menemukan sendiri pembahasan dari permasalahan yang diberikan. Hasil penelitian ini sejalan dengan penelitian yang dilakukan oleh Said, et al., (2016), dimana diperlukan produk pembelajaran yang dikembangkan pada tingkat yang valid dan reliabel digunakan sebagai produk pembelajaran saintifik. Penilaian fasilitas online yang tergolong baik dengan rerata skor 3,5 4,5. SMP di perkotaan Bali sudah terjangkau komputer dan paling tidak soft copy dari informasi yang diunduh dari online (informasi off-line) dapat dimiliki guru. Hal ini didukung oleh penelitian Anas et al., (2015) bahwa sekolah perkotaan sebagain besar memiliki ruang komputer dengan akses internet yang baik.

Stakeholders menilai prasarana meliputi ruang belajar, perpustakaan, ruang komputer, dan transportasi menuju sekolah tergolong baik dengan rerata skor 3,5 - 4,5. Hampir semua SMP di Bali sudah memiliki itu semua yang memadai, kecuali ruang komputer. Semenjak komputer laptop atau notebook dan handphone dengan memori yang cukup besar dapat dimiliki paling tidak oleh guru, informasi online tidak lagi satu-satunya harus diakses melalui ruang computer. Tetapi dapat juga diakses dari ruang mana saja dan bahkan di luar ruangan, sehingga penilaian terhadap ketersedian ruang komputer tergolong baik. Ruang belajar di daerah perkotaan sudah sangat memadai, dari penelitian yang dilakukan Anas et al., (2015), bahwa fasilitas didalam kelas sekolah 
diperkotaan jauh lebih baik dan sudah mendukung segala aktifitas peserta didik. Transportasi diperkotaan sangat mudah diakses dikarenakan banyaknya kendaraan umum yang meringankan beban orang tua untuk mengantar dan menjemput anaknya, bahkan beberapa sekolah diperkotaan sudah menyediakan bus sekolah. Perpusatakan sekolah sebagai tempat peserta didik untuk secara mandiri belajar dan mencari refrensi di sebagian besar sekolah di kota Bali sudah dikelola dengan baik. Hasil penelitian ini didukung oleh penelitian yang dilakukan oleh Mujahid \& Norman (2015) yang menyatakan bahwa pentingnya transportasi yang memadai demi keberlangsungan proses pembelajaran, dengan adanya transportasi yang memadai baik peserta didik maupun guru dapat sampai tepat waktu di sekolah. Sama, halnya dengan keberadaan perpustakaan sekolah yang membantu peserta didik dalam meningkankan kwalitas membaca mereka.

Kondisi belajar meliputi keterlibatan siswa dalam pra-pembelajaran $5 \mathrm{M}$, konsistensi kegiatan belajar $5 \mathrm{M}$, suasana, budaya membaca di rumah, dan pekerjaan orang tua (ekonomi) dinilai baik oleh stakeholders. Hasil penelitian ini sejalan dengan pendapat dari Print \& Muray (1993) bahwa untuk mendesain kurikulum diperlukan perhatian dalam beberapa elemen penting yang mendukung terbentuknya kurikulum, salah satunya elemen kurikulum termasuk analisis situasional, maksud, isi, kegiatan pembelajaran, dan evaluasi. Dengan analisis situasional maka dapa diketahui situasi yang dapat menghasilkan perubahan perilaku (performance) pada seseorang setelah ia ditempatkan pada situasi tersebut. Menurut penelitian yang dilakukan oleh Shindler (2001) faktor yang perlu diperhatikan dalam menciptakan iklim kelas yang berkualitas dan kondusif guna meningkatkan prestasi belajar siswa, antara lain pendekatan pembelajaran hendaknya berorientasi pada bagaimana siswa belajar (student centered). Kegiatan 5M sendiri membiasakan dan melatih siswa, bahwa mereka belajar sendiri dengan menemukan konsep dan pengetahuan, serta pendekatan saintifik ini berpusat pada siswa.

Secara umum kota di Bali, mayoritas siswa SMP sudah tidak lagi harus membantu orang tua mencari nafkah. Pembebasan SPP (sumbangan penyelenggaraan pendidikan) pada siswa, tersedianya dana bantuan opersasi sekolah yang cukup memadai dan bantuan beasiswa dalam bentuk kartu pintar atau sejenisnya dapat membantu orang tua yang kurang mampu untuk menyekolahkan anaknya. Hasil penelitian ini didukung oleh Herwan et al., (2018) bahwa peran komite sekolah yaitu orang tua peserta didik di daerah perkotaan telah menjalankan perannya sebagai lembaga penasehat, sebagai lembaga pendukung, sebagai agen pengendali, dan sebagai agen mediator.

Membaca merupakan kegiatan yang wajib dilakukan peserta didik di rumah, buku penunjang yang diberikan oleh pihak sekolah diharapkan dapat membantu peserta didik untuk meningkatkan budaya membaca meskipun di zaman teknologi seperti sekarang akses membaca dapat dilakukan dimapun dan kapanpun melalui smartphone dan sebagainya. Diharapkan dengan kemudahan tersebut dapat meningkatkan minat membaca peserta didik, sehingga respon stakeholder menilai baik budaya membaca di rumah. Namun lagi keterlibatan siswa dalam persiapan atau prabelajar dan konsisten belajar melalui kegiatan $5 \mathrm{M}$ cendrung kurang realistis, karena kecendrungan LKS hanya berupa petunjuk kerja dan/atau latihan soal yang diberikan guru lebih banyak ditemukan di lapangan. Hasil penelitian ini didukung oleh Wahyono et al., (2017) bahwa diperlukannya perangkat pembelajaran yang selaras dan konsisten menggunkan pendekatan saintifik, bukan hanya gambaran umumnya saja sehingga masih membingungkan peserta didik.

Stakeholders menilai profesionalisme guru yang meliputi latar belakang pendidikan/sertifikasi guru, pemahaman belajar dengan pendekatan saintifik, identifikasi empat jenis pengetahuan terkait (pengetahuan konseptual, prosedural, faktual, dan metakognitif), pengembangan PBS, operasional dan tingkat bimbingan implementasi LKPD 5M (student-centered) tergolong baik dengan rerata skor 3,5-4,5. Jika konsen dengan temuan di lapangan dan dari hasil observasi awal, bahwa sulit menemukan buku pelajaran dan/atau LKPD yang konsisten mengikuti penalaran penemuan $5 \mathrm{M}$ dan kualitas belajar IPA untuk usia sekitar 15 tahun masih tetap rendah (OECD,2016), penilaian profesionalisme yang tergolong baik adalah kurang realistis. Hasil penelitian ini didukung oleh penelitian yang dilakukan oleh Driel et al., (2001) bahwa untuk mengembangkan profesionalisme pengetahuan praktis guru diperlukan pelatihan pengetahuan praktis yang mengintegrasikan pengetahuan pengalaman, pengetahuan formal, dan kepercayaan pribadi. Program pelatihan pengembangan profesionalisme guru perlu 
dilakukan dalam jangka panjang untuk mencapai perubahan pengetahuan praktis yang langgeng dalam guru. Belum tersedianya panduan/instruksi penegasan acuan/benchmarks kualitas masing-masing fase $5 \mathrm{M}$ yang saintifik pada sekolah dan mayoritas guru sudah mengikuti sertifikasi guru, sehingga guru maupun kelompok stakeholders yang lain memberikan penilaian baik. Meskipun ada temuan Bank Dunia bahwa peningkatan jumlah guru yang memiliki sertifikasi guru belum cukup meningkatkan kualitas belajar di Indonesia. Pemerintah sudah gencar mengadakan pelatihan dan pembinaan terhadap guru guna merancang pembelajaran dengan pendekatan saintifik yang konsisten dan selaras. Hal ini sejalan dengan penelitian yang dilakukan oleh Cheruvu (2014) bahwa selain mengajar guru harus memiliki kemampuan untuk penelitian sehingga kemampuan keterampilan kerja ilmiah guru pun akan membaik. Selain hal di atas, diperlukan tentor yang memang sudah berpengalaman dan mampu untuk membina guru-guru serta pedoman acuan/benchmarks saintifik. Diharapakan dengan demikian guru-guru di perkotaan Bali mampu membuat perangkat pembelajaran dengan pendekatan saintifik.

Terakhir, stakeholders menilai sistem pengelolaan sekolah yang meliputi dukungan otoritas sekolah (yayasan pemilik sekolah dan/atau Dinas Pendidikan dan Olah Raga), staf pengelola sekolah, MGMP (asosiasi profesi pendidikan lainnya), dan dukungan masyarakat adalah tergolong baik dengan rerata skor 3,5 4,5. Hal ini cendrung berhubungan dengan dukungan dana penyelenggaraan pendidikan minimal yang diberikan atau dipersyaratkan dalam penyelenggaraan sekolah sudah dapat dipenuhi oleh mayoritas SMP di Bali melalui bantuan pemerintah atau pemenuhan kewajiban oleh yayasan pemilik sekolah.

$$
\text { Penilaian stakeholders terhadap }
$$
profesionalisme guru dan pengelolaan sekolah cendrung lebih baik dari realitas, dengan beberapa fakta lapangan yang telah diungkapkan di atas. Hal demikian cendrung terjadi terutama karena belum adanya ketegasan acuan (benchmarks) kriteria kualitas masingmasing tahapan 5M seperti Benchmarks for Science Literasi (American Association for the Advancement of Scinece, 1993) yang diamanatkan untuk diwujudkan oleh guru yang didukung oleh semua pihak. Di samping itu, penilaian kelulusan siswa maupun akreditasi sekolah masih berkesan pada formalitas skor pengetahuan dan kuantitas lulusan. Kenyataan bahwa ketuntasan belajar melalui program remedial cendrung hanya formalitas. Banyak siswa yang diformalkan mengikuti program remedial akhirnya diberi skor ketuntasan minimal dengan berbagai alasan seperti keterbatasan waktu dan tuntutan akreditasi sekolah, meskipun sebenarnya ketuntasan penguasaan kompetensi belum tercapai. Kenyataan demikian cendrung menjadi latar terutama kelompok guru SMP sebagai pihak penyelenggara dan guru bidang IPA SMA (guru Fiska, Kimia, dan Biologi SMA) sebagai pihak pengguna yang juga memiliki profesi guru agak sedikit subjektif pada loyalitas kelompok seperti temuan Ramsey (2014) bahwa orang tua rata-rata melaporkan persepsi yang lebih buruk dari keterlibatan orang tua dan komunikasi orang tua-sekolah, dan guru melaporkan persepsi yang lebih buruk dari lingkungan belajar tetapi kepuasan keseluruhan yang lebih besar dengan sekolah mereka dibandingkan dengan orang tua dan siswa. Secara keseluruhan, tampaknya informan cenderung memberikan penilaian yang lebih rendah terhadap dimensi iklim yang paling terkait langsung dengan perilaku mereka (yaitu: siswa: keselamatan sekolah, staf: lingkungan belajar, orang tua: keterlibatan orang tua dan komunikasi). Namun, meskipun peringkat iklim sekolah ini secara statistik berbeda secara signifikan antara informan, kami tidak dapat menentukan dari hasil kami jika perbedaan ini memiliki implikasi yang bermakna bagi hasil siswa dan sekolah. Untuk menjawab pertanyaan tentang kepentingan praktis ini, penelitian masa depan harus melihat bagaimana skala yang dimaksudkan untuk mengukur dimensi yang sama dari iklim sekolah dari perspektif informan yang berbeda berkaitan dengan hasil akademik dan perilaku siswa, serta kualitas guru dan hasil kinerja (pergantian, pengalaman, dll.).

Namun demikian, hasil ini menunjukkan pentingnya mempertimbangkan jenis informan ketika mengevaluasi peringkat iklim di sekolah.Meskipun demikian, sebagai guru yang mengemban tanggungjawab moral untuk selalu meningkatkan kualitas belajar, mereka setuju penawaran kebutuhan konsistensi implementasi setiap fase $5 \mathrm{M}$ yang semestinya dilakukan sebagai langkah-langkah integral dalam penalaran ilmiah (angket perangkat pertama).

Seperti halnya telah diungkap, stakeholders memahami dan menyadari bahwa 
penerapan PBS IPA secara konsisten tidak selalu memerlukan alat dan bahan khusus (temuan pengetahuan cendrung masih sederhana yang masih bisa menggunakan data kualitatif), tetapi terdapat kepercayaan terhadap penyelenggara akan mampu mengelola PBS secara secara konsisten dengan menggunakan alam semesta sebagai laboratorium belajar IPA. Penilain keseluruhan stakeholders terhadap iklim pembelajaran IPA SMP dalam rangka pengembangan perangkat pembelajaran dengan pendekatan saintifik tergolong baik, menunjukkan dukungan yang kuat terhadap pengembangan PBS melalui $\mathrm{R} \& \mathrm{D}$. Hal ini mendukung deskripsi latar belakang kenyataan masih sulit menemukan perangkat pembelajaran IPA SMP (RPP, LKPD, teks materi pelajaran, dan asesemen) untuk suatu unit pelajaran yang selaras dan konsisten mengikuti pendektan saintifik dan fakta kualitas pembelajaran sains di Indonesia masih tetap rendah (OECD, 2015).

\section{Simpulan dan Saran}

Simpulan

Stakeholders mendukung kebutuhan pembelajaran aspek-aspek keterampilan kerja ilmiah dengan presentase dukungan keseluruhan aspek yaitu 92,7\%. Materi IPA SMP yang diprogramkan kurikulum dapat memfasilitasi pembelajaran dengan pendekatan saintifik dengan presentase dukungan oleh stakeholders 93,7\%. Iklim pembelajaran IPA SMP pada wilayah kota di Bali dibatasi pada profesionalisme guru, pengelolaan sekolah, kondisi belajar (setting belajar dan budaya belajar di masyarakat), sarana, dan prasarana belajar sains adalah tergolong baik dengan rerata skor 4,33.

Saran

Penelitian selanjutnya dapat diterapkan pada skala kecil agar ketepatan sasaran aspekaspek kebutuhan keterampilan kerja ilmiah dan materi IPA serta situasi pembelajaran dengan pendekatan saintifik kajiannya lebih mendalam. Ucapan Terima Kasih

Ucapan terimakasih disampaikan kepada semua pihak stakeholders penyelenggaraan Pendidikan IPA SMP pada wilayah kota di Bali yang telah bersedia memberikan tanggapan terhadap kebutuhan dan penilaian terhadap situasi pembelajaran IPA SMP dengan pendekatan saintifik.

\section{Daftar Pustaka}

Adam, R.G. \& Gullota, T. (1983). Adolescent Life Experiences. California: Brooks/Cole Publishing Company.
American Association for the Advancement of Scinece. (1993). Benchmarks for Science Literacy: Project 2061. NewYork : Oxford University Press.

Anas, A. Y., Riana, A.W., \& Apsari, N.C. (2015). Desa dan kota dalam potret pendidikan. Proseding Konaspi, 2(3), 304-444.

Arianty, W.N., Febriana, B.W., Diniaty, A. (2017). An analysis of learning process based on scientific approach in physical chemsitry experiment. AIP Conference Proceedings.Dalamhttps://aip.scitation.or g/doi/10.1063/1.4978157.DOI:10.1063/1. 4978157.

Borg, W. R. \& Gall, M. D. (1989). Educational Research. Fifth Edition. New York: Longman.

Chatab, Nevizond. (2007). Keterampilan Saintifik. Jakarta: Serambi Ilmu Semesta.

Cheruvu, R. 2014. Focus on teacher as researcher: Teacher educators as teacher researchers: practicing what we teach. Journal of Childhood Education, 90 (3), 225-228.

Creswell, J. W. (2008). Research Design: Qualitative, Quantitative, and Mixed Methods Approaches. California: Sage Publications.

Driel, J. H., Beijaard, D., \& Verloop, N. (2001). Professional Development and Reform in Science Education: The Role of Teachers' Practical Knowledge. Journal of research in science teaching, 38 (2), 137-158.

Firman, H. (2007). Analisis Literasi Sains Berdasarkan Hasil PISA Nasional Tahun 2006. Jakarta: Puspendik.

Herwan., Aswandi., \& Chiar,M. (2018). The role of school committee in supporting the fulfillment of education facilities and infrastructure. Journal of education and learning, 3(2), 282-287.

Hewitt, Paul G. (2007). Conceptual Integrated Science. USA: Pearson Education

Islami, R.A.Z.E. (2013). Pembelajaran inkuiri terbimbing untuk meningkatkan literasi sains dan kepercayaan diri siswa pada konsep larutan asam basa. Skripsi. Bandung: Universitas Pendidikan Indonesia.

Kaufman, R. A. (1972). Educational System Planning. New Jersey: Prentice-Hall, Inc. 
Lavesson, N. (2017). Rural-Urban Interdependenciesn - The Role of Cities In Rural Growth. Doctoral Dissertation. Sweden: the Faculty of Social Sciences, Lund University. Dalam http://portal. research.lu.se /ws/files/25611085Lavesson_ 2017. pdf. Diakses 20 Agustus 2018.

Li, Juan. (2014). Needs analysis: an effective way in business english curriculum design. Journal of Theory and Practice in Language Studies, 4(9),1869-1874.

Mujahid, N. \& Noman, M. (2015). Infrastructure availability in the public sector schools: a case study of sindh province. Journal of Education and Practice, 6(4), 60-67.

National Academy of Science. (1996). National Science Education Standars. Washington DC: National Academy Press.

OECD. (2015). PISA 2015 Assessment and Analytical Framework-Science, Reading, Mathematics and Financial Literacy. Paris: OECD Publishing.

OECD. (2016). PISA 2015 Results Excellence and Equity in Education. Vol I. Dalam from http:/www. pisa.oecd.org. Diakses 3 Oktober 2018.

Pateman, T. (2011). Rural and Urban Areas: Comparing lives Using Rural/Urban Classifications. Regional Trends 43. UK: Office for Statistics. Dalam https://webarchive.nationalarchives.go v.uk/20160129150406/http://www.ons. gov.uk/ons/rel/regionaltrends/regional-trends/no--43--2011edition/rural-and-urban-areas-comparing-lives-using-rural-urbanclassifications.pdf. Diakses 20 Agustus 2018.

Print \& Murray. (1993). Curriculum Development and Design. Publishes online in A \& $U$ Academic dalam http://faberwritingacademi.com.au. ISBN: 9781863733625.

Ramsey, C.M. (2014). School Climate, Older Adult Characteristics, and Fullfilment of School-Based Volunteer Roles in the Baltimore Experiece Corps- $A$ dissertation submitted to Johns Hopkins University. Dalam https://jscholarship.library.jhu.edu/bitstr eam/handle/1774.2/37961/RAMSEYDI SSERTATION-2014.pdf. Diakses 30 Desember 2018.
Riduwan. (2012). Metode \& Teknik Menyusun Proposal Penelitian. Bandung Alfabeta.

Said, I.M., Sutadji, S., \& Sugandi, M. (2016). The scientific approach-based cooperative learning tool for vocational students vocation program of autotronic (automotive electronic) engineering. Journal of Research \& Method in Education, 6(3), 67-73.

Sandoval, W.A. \& Harven, A.M. (2011). Urban middle school students' perceptions of the value and difficulty of inquiry. Journal Science Education Technologi. 20(1) ,95-109.

Shen, M.M. (2007). Guided discovery Teaching in Primary Schools to Improve Learning Outcomes evaluated from Independence Students. Thesis. Dalam https://core.ac.uk/download/pdf/123473 11.pdf. Diakses 27 Oktober 2018.

Shindler, J. (2001). Improving classroom climate and student achievement by assessing student participation. Journal of Research in Science Teaching, 28(2), 193-209.

Stokes, H., Roger, H \& Stafford, J. (1999). Final Report Rural and Remote School Education. Published online in Melbourne, Vic. : Youth Research Centre, University of Melbourne https://www.worldcat.org/title/ruraland-remote-school-education. OCLC Number: 46880435

Sudjana, Nana. (2004). Dasar-Dasar Proses Belajar-Mengajar. Bandung: Sinar Baru.

Sudria, I. B. N. (2006). Pengembangan Materi Pembelajaran Kimia Di SMP dalam Rangka Pendidikan "Science for All". Disertasi. Universitas Pendidikan Indonesia.

Sudria, I. B. N. (2016). Pengembangan Perangkat Pembelajaran Saintifik dengan Penalaran Dasar Induktif dan Deduktif. In A. Premono, I. W. Sugita, R. Sukarno, \& M. A. Akbar (Eds.). Proseding Konaspi VIII, 731-740. Jakarta: Universitas Negeri Jakarta.

Susbiyanto \& Insih Wilujeng. (2016). Pengembangan Perangkat IPA Berbasis Kurikulum 2013 Untuk Meningkatkan Keterampilan Proses, Kejujuran, Dan Tanggung Jawab. Artikel Imiah Pascasarjana UNY. Dalam https://media.neliti.com/media/publicati ons/122823-ID-pengembangan- 
perangkat-ipa-berbasis-kuri.pdf.

Diakses 24 Januari 2019.

Trefil, James \& Hazen Robert. (2007). The Sciences, An Integrated Approach. USA: John Wiley and Sons, Inc.

Utami, W.S. \& Kurniawati, A. (2018). Pendalaman Materi Georgrafi Modul 7 Interaksi Desa - Kota. Ristekdikti. Dalam DAR2/ Profesional /207/ 007/ 2018. Diakses 29 November 2018.

Wahyono., Abdulhak, I., Rusman. (2017). Implementation of scientific approach based learnin to think high levels in state senior high school in Ketapang. International Journal of Education and Research, 5(8), 221-230.

Wiliyanti, Vandan., Eko Suyanto, \& Abdurrahman. (2015). Pengembangan
Perangkat Pembelajaran IPA Terpadu Berorientasi Pendidikan Karakter Pada Model Pembelajaran Exclusive. Artikel Ilmiah. Dalam https://media.neliti.com /media/publications/120058-IDpengembangan-perangkatpembelajaran-ipa.pdf. Diakses 24 Januari 2019.

Zhang, Yongmei. (2013). Study on the rural primary and secondary school english teachers training curriculum-based on ' national training projects' (NTP). Artikel pada koferensi International Journal of Conference on Management Science and Industrial Engineering (MSIE 2013). Published by Atlantis Press. 